\title{
Moderating Role of Materialism in the Effect of Perceived Value on Purchase Intention of Counterfeits of Luxury Brands
}

\author{
Selma Kalyoncuoglu ${ }^{1} \&$ Begum Sahin ${ }^{2}$ \\ ${ }^{1}$ Department of Business Administration, Faculty of Economics and Administrative Sciences, Gazi University, \\ Ankara, Turkey \\ ${ }^{2}$ Department of International Trade, Faculty of Economics and Administrative Sciences, Cankaya University, \\ Ankara, Turkey \\ Correspondence: Selma Kalyoncuoglu, Department of Business Administration, Faculty of Economics and \\ Administrative Sciences, Gazi University, Muammer Bostanci Cad., Besevler, Ankara, Turkey. Tel: \\ 90-312-216-1253. E-mail: selmakalyoncuoglu@gmail.com
}

\author{
Received: May 26, 2017 Accepted: June 28, $2017 \quad$ Online Published: July 28, 2017 \\ doi:10.5539/ijms.v9n4p76 URL: http://doi.org/10.5539/ijms.v9n4p76
}

\begin{abstract}
The use of counterfeits of luxury brands has become a phenomenon in Turkey in recent years since they are the most significant facilitator for consumers to reach luxury consuming products. Limited number of studies in the literature shows that consumers prefer counterfeits of luxury brands for a variety of reasons. Within this study, it is believed that perceived value of products in consumers' minds and consumers' materialistic tendencies demonstrating the worth attached to physical assets could have an impact on their purchase intention of counterfeits of luxury brands. Within this framework, this study aims to identify the effect of perceived value on consumer purchase intention of counterfeits of luxury brands and the moderating role of materialism in this effect. Data of the study are being collected through face-to-face survey method with university students who have bought and used counterfeit products before. Exploratory Factor Analysis is carried out for construct validity and reliability of the research model, and relationships between variables are measured with Hierarchical Regression Analysis to test the model. The result expected to be reached based on the findings of the study is to be able to present whether the relationship between consumers' perceived value of counterfeit products and their purchase intention of counterfeits of luxury brands are dependent on consumers' materialistic tendencies. Therefore, it is envisaged that consumers who have high materialistic tendencies will show more purchase intention of counterfeits of luxury brands compared to consumers having low materialistic tendencies when they perceive high value for counterfeit products. However, it was found that materialism did not have any moderating role in the effect of perceived value of counterfeit products on purchase intention of counterfeits of luxury brands.
\end{abstract}

Keywords: counterfeit products, perceived value, materialism, purchase intention, moderating effect

\section{Introduction}

A brand can be defined as "a name, term, sign, symbol, or design, or combination of them which is intended to identify the goods and services of one seller or group of sellers and to differentiate them from those of competitors" (Kotler, 1991, p. 442). The brand name and all the related things about it are very crucial for the company's competitive advantage and also for the future earnings (Aaker, 1991).

Global companies spend huge amount of money for their branding activities to build a strong brand equity. However many people around the world tend to purchase counterfeit products instead of the originals. This tendency has become a phenomenon since 1970's and today it is a serious threat. However the demand is getting higher and the market is growing day by day. As the technological improvements increased and affected the manufacturing process, the copies of genuine products have had no longer low quality (Penz \& Stottinger, 2005; Gentry et al., 2006). Counterfeits of well-known luxury brands such as Cartier, Chanel, and so on, address to feelings of consumers who cannot afford to purchase the original (Wilke \& Zaichkowsky, 1999, p. 10).

"Trade in Counterfeit and Pirated Goods" Report of The Organisation for Economic Co-operation and Development (OECD) proves that in 2013, international trade in such products represented up to $2.5 \%$ of world 
trade or as much as USD 461 billion. This is the equivalent of the GDP of Austria, or the combined GDP of Ireland and the Czech Republic. Above all, it highlights that right holders, governments and the formal economy as a whole suffer from significant economic and social losses (The Organisation for Economic Co-operation and Development [OECD] / European Union Intellectual Property Office [EUIPO], 2016, p. 11). Counterfeit products range from high-end consumer luxury goods such as watches, perfumes or leather goods, to business-to-business products such as machines, chemicals or spare parts, to common consumer products such as toys, pharmaceuticals, cosmetics and foodstuffs (OECD/EUIPO, 2016, p. 12).

According to the same report of OECD, China is the leader in production and its market on counterfeit and pirated goods has a ratio of 63.2, while Turkey has 3.3 with a market worth USD 10.8 billion. This amount also means $0.98 \%$ of Turkey's export includes counterfeit and pirated goods. USA, France and Italy are the countries that get affected the most.

As brand equity of luxury brands gets stronger over time, brand image and prestige also get powerful. This in turn attracts consumers' purchasing habits of luxury brands (Yoo \& Lee, 2009, p. 280). The counterfeit producers directly get benefit through the brand names without any cost of marketing activities (Furnham \& Valgeirsson, 2007). Wilke \& Zaichkowsky (1999) has called this easy earning destroys the brand equity and company's reputation. There is a damaging effect on the image of the brand that is built by the original company (Hieke, 2010) and also to the industrial competitiveness of the nation as well (Bloch et al., 1993).

In the first quarter of 2016, parliament of the Republic of Turkey introduced a bill on Intellectual Property Rights to prevent the illegal trade of counterfeit goods that weakens the economy and the prestige of the country, and causes a severe loss for the country. The bill was then signed into law on January 10th, 2017 and named as Industrial Property Law No. 6769. According to the legal sanction imposed by the Law, producers and also sellers of counterfeit goods shall face trial and the penalty could be a fine or 1-3-year imprisonment (http://www.resmigazete.gov.tr/eskiler/2017/01/20170110-9.htm).

Since the issue had become crucial, the academic studies (Eisend \& Schuchert-Guler, 2006; Albers-Miller, 1999; Wiedmann et al., 2007; Ang et al., 2001; Bloch et al., 1993; Fernandes, 2013; Tom et al., 1998; Gentry et al., 2006; Wee et al., 1995; Yoo \& Lee, 2009; Penz \& Stottinger, 2005; Engizek \& Sekerkaya, 2015a; Hennigs et al., 2015) focused on the demand side of the counterfeiting of luxury brands.

The present study aims to investigate the relationship between the consumers' perceived value and purchase intention of the counterfeits of luxury products. The main difference and the contribution to the literature of this research are to identify the moderating role of materialism on the issue. Moreover, the consumers of the research sample are aware that the product is counterfeit and they consciously decide to purchase it. This situation is accepted as non-deceptive counterfeiting in the literature (Grossman \& Shapiro, 1988).

According to the results of similar research, young people tend to buy counterfeit goods (Tom et al., 1998; Wee et al., 1995) and tend to be more materialistic (Belk, 1985; Csikszentmihalyi \& Rochberg-Halton, 1981). Therefore the data collection of the present research is selected from the university students born between the years 1992 and 1999.

\section{Literature Review}

\subsection{Perceived Value of Counterfeit Products}

Luxury brands are perceived as more valuable as they provide superior quality and reassurance to the consumers (Aaker, 1991). The brand name is the main reflector of superior quality (Gentry et al., 2001). Some consumers deeply believe that the original and the counterfeit product have the same quality level (Penz \& Stottinger, 2008) As consumers save money and have economic benefits, this fact makes the counterfeits valuable and not inferior (Albers-Miller, 1999; You \& Lee, 2009) because they get prestige without paying too much (Bloch et al., 1993; Tom et al., 1998; Ang et al., 2001).

Consumers fully assess products depending on their judgment of gain and loss; this overall value judgment is identified as perceived value (Zeithaml, 1988, p. 14). Therefore it is accepted as a trade-off of get-and-give components. While one of the get components is quality, the latter one could be money, time or effort (Zeithaml, 1988).

Brand equity affects the customer by giving value. This in fact provides information and confidence for the purchasing decision (Aaker, 1991). The perception of value directly influences willingness to buy (Dodds et al., 1991, p. 308). Therefore companies should focus on this trade-off and make best use of it. As the perceived value is analysed deeply by the marketing managers, they become closer what the consumers exactly want. 
Monroe \& Krishnan (1985), Rao \& Monroe (1989), Zeithaml (1988), Dodds et al. (1991) examined the relationship between price and perceived quality of consumers. Dodds \& Monroe (1985) and Grewal et al. (1998) studied on the relationship of perceived value and purchase intention of counterfeit products. Vigneron and Johnson's model (1999) found out that conspicuous value, unique value, social value, emotional value and quality value are five fundamental perceived values. They directly affect the consumer preferences particularly for luxury brands. In their study, Wiedmann et al. (2007) define the dimensions which could explain consumer behaviour related to luxury brand purchasing as financial, functional, individual and social ones and combined them into a single framework. The term "luxury" and the consumption of luxury goods involve purchasing a product that represents value to both the individual and their reference group (Wiedmann et al., 2007, p. 333). The desire to consume luxury products is not only for the personal satisfaction, luxury products are also effective tools to impress others in this way people enhance their own image and increase their social status in the society (Nia \& Zaichkowsky, 2000).

Among the latest researches, Sweeney \& Soutar (2001) proposed perceived value scale (PERVAL scale) and explained its four dimensions. Emotional value means the utility derived from the feelings or affective states that a product causes in people, social value results from the product's ability to enhance social self-concept and two types of functional value are denoted as price/value for money and as performance/quality. Price/value for money is derived from the reduction of product's perceived short term and longer term costs and performance/quality designates the perceived quality and expected performance of the product (Sweeney \& Soutar, 2001, p. 211). PERVAL scale is based on the study of Sheth et al. (1991) but it includes multiple items as an extensive approach. The scale demonstrates that consumers assess products, not just in functional terms of expected performance, value for money and versatility; but also in terms of the enjoyment or pleasure derived from the product (emotional value) and the social consequences of what the product communicates to others (social value) (Sweeney \& Soutar, 2001, p. 216).

\subsection{Purchase Intention for Counterfeits of Luxury Brands}

In terms of consumers, brand equity means "value added" to products in this way consumers form a link between brand equity and brand name. Although "value added" can have a number of dimensions, its main components are of significant importance in analysing brand purchase intent and behaviour (Netemeyer et al., 2004, p. 210). If the consumer has a willing to pay for a product or service, the reason behind it is that he or she intends to purchase it. Since the consumer has the purchase intention, this is also the main indicator of brand loyalty (Aaker, 1991).

When consumers purchase the counterfeit product, they feel the prestige of the original brand because the physical appearances look similar to each other very much.

Consumers who have high income and could afford to purchase the original luxury brands don't have prefer to use the counterfeits because they believe that buying original products is an admiration and it means acceptance in the society and they consider counterfeits as inferior (Nia \& Zaichkowsky, 2000).

According to Yoo \& Lee (2009), past purchase behaviour has the strongest effect on the consumption of luxury fashion brand counterfeits. Once a consumer has an experience of buying a counterfeit, this attitude could turn into a habit. In order to avoid counterfeits, luxury-brands try to improve their manufacturing process so that they cannot be copied easily. However the main issue is to impress the demanding side by promoting "counterfeit purchase" an issue like a crime (Yoo \& Lee, 2009).

When the perceptions of the consumers towards the counterfeit products change negatively in the minds, this new fact directly affects the purchasing intentions as well. The feeling of quilt and regret of the experience could arise and this could prevent the intention of the consumers who have tendency to purchase and consume counterfeit products.

Although many consumers are aware of the illicit act mentioned above, they still carry on their interest for counterfeit products. This kind of consumer attitude was also examined academically (Cordell et al., 1996). Based on Walker's (1977) research, people get satisfaction from their unethical attitudes and they tend to break the rules.

Price can be regarded as the main motivation of the purchasing intention of counterfeit products (Tom et al., 1998; Bloch et al., 1993; Albers-Miller, 1999; Ang et al., 2001) as the consumers don't mind the ethical side of the action and try to get benefit from economic advantage compared to the genuine ones.

Consumers get economic advantage as paying less for the counterfeit products than the originals therefore tolerate the quality constraint of them (Dodge et al., 1996). Because of the cost savings, perceived value of 
counterfeits becomes high and affects the consumers to prefer the counterfeit ones (Bloch et al., 1993).

According to the examination of Nia \& Zaichkowsky (2000), most of the consumers are aware the exclusivity and better quality of the genuine products therefore although they purchase the counterfeits, this situation does not affect their desire to own the original products instead of the counterfeit ones and the demand to the original ones does not decrease.

\subsection{Materialism}

Materialism can be defined as importance that consumers place on goods or products they buy (Belk, 1984, p. 291). Therefore, it could be helpful to anticipate whether people want to buy counterfeits or not (Furnham \& Valgeirsson, 2007, p. 678).

Consumers get the prestigious of the brand name and also identical appearance of the genuine product when they purchase the counterfeit ones. Materialist consumers care more about their physical appearance and self-image because of vanity (Netemeyer et al., 1995). Therefore it is more probably caused that the consumers with materialistic values have more tendency to consume counterfeit products Chuchinprakarn (2003) and Yoo \& Lee (2009) proved the positive relationship between materialism and purchase intention of counterfeits through their research. Also Engizek \& Sekerkaya (2015b) proved that for people who are more materialistic, their social status in the society is important and they like to increase it anytime with the possessions they own (Belk, 1985; Richins, 1994; Fitzmaurice \& Comegys, 2006; Sun et al., 2014).

Belk's (1985) scale measures materialism with its three features which are possessiveness, nongenerosity and envy. Possessiveness can be defined as "the inclination and tendency to retain control or ownership of one's possessions" (Belk, 1983). Possessions are seen as (Belk, 1982): Reasonably tangible, but may include certain experiences (e.g., last year's vacation-“I've been there/done that"), tangible assets (including money, contracts, monetary obligations and interests, and land), and even other persons (where some identification with and mastery or control over these persons exist—e.g., "my employee/friend/child/legislator") (Belk, 1985, p. 267).

The conceptual domain for non-generosity includes an unwillingness to share possessions with others, a reluctance to lend or donate possessions to others, and negative attitudes toward charity. The domain for the envy construct involves a desire for others' possessions, be they objects, experiences, or persons (Belk, 1985, p. 268).

Richins \& Dawson (1992) measure materialism through three dimensions which are acquisition centrality, acquisition of the pursuit happiness and possession-defined success. The acquisition centrality explains that the materialistic individuals placed the materials they own in the centre of their lives, they care about them. Also this is the source of their happiness as the possessions are crucial to be happy and satisfied. And also the more, one owns materially, the more successful he or she is in the life. This is the main indicator for them that they are successful (Richins \& Dawson, 1992).

Richins \& Dawson (1992) scale is more preferred by the researchers to measure the materialism (Furnham \& Valgeirsson, 2007; Swami et al., 2009; Wan et al., 2009; Lu \& Lu, 2010; Sun et al., 2014; Netemeyer et al., 1995; Engizek \& Sekerkaya, 2015b). Richins \& Dawson's (1992) scale is accepted as more valid and reliable compared to Belk's (1985) scale (Furnham \& Valgeirsson, 2007) as in the present study it is preferred for the measurement as well.

\section{Hypotheses and the Model}

First of all, theoretical framework is exhibited in this empirical research to determine the role of materialism on the effect among perceived value of counterfeit products and purchase intention for counterfeits of luxury brands. Literature is examined thoroughly and hypotheses are designed based on the literature review. The relationship between perceived value of counterfeit products and purchase intention for counterfeits of luxury brands is analysed and then this relationship is examined in terms of the moderating role of materialism.

In this regard, the hypotheses are:

H1: Consumers' perceived value of counterfeit products has a positive and meaningful effect on their purchase intention for counterfeit luxury brands.

H2: Materialism has a moderating role in the effect of consumers' perceived value of counterfeit products on the purchase intention for counterfeit luxury brands. 


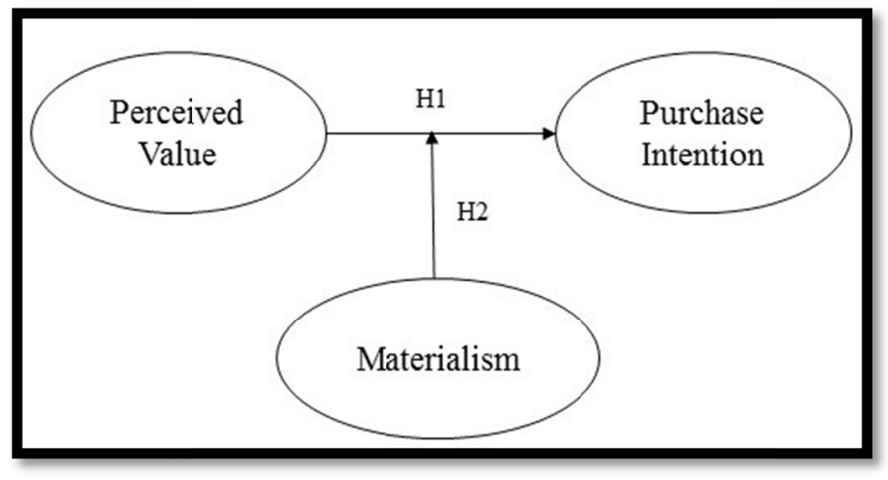

Figure 1. Hypothetical research model

\section{Methodology of the Research}

In this study which investigates the effect of consumers' perceived value (PVoCP) of using a luxury brand even if it is counterfeit on purchase intention of the counterfeits of luxury products (PIoCoLB) as well as the moderating role of materialism (M) in this effect, the aim was to reveal whether the data gathered with a survey was supported with the model developed based on theoretical background. Within this regard, sampling process and data collection method, scales used in the study and designing survey form and finally data analysis method were explained below respectively.

\subsection{Sampling Process and Data Collection Method}

The population of the study was composed of a total of 7915 students who were registered at Gazi University Faculty of Economics and Administrative Sciences during fall semester of 2016-2017 academic year. In a study on usage of counterfeits of luxury brands, it was stated that the aforementioned population was appropriate for evaluating perceived value and materialistic tendency.

Judgmental sampling which is based on collecting data from a sample that is appropriate for the purpose of the research was preferred to use in determining respondents (choosing those who have used counterfeits of luxury brands at least once as working group), and convenience sampling which involves selecting subjects from the population who are easily accessible was preferred for the research (choosing students of Gazi University Faculty of Economics and Administrative Sciences because of time and budget constraints). Within this scope, in determining the sample size, the formula $\mathrm{n}=\pi(1-\pi) /(\mathrm{e} / \mathrm{Z})^{2}$ was applied considering the nature of the study and it was determined that necessary lower boundary should be 384 with $5 \%$ margin of error and $95 \%$ confidence level (Kurtulus, 2010, p. 67).

The survey was administered between $21^{\text {st }}$ November and $2^{\text {nd }}$ December, 2016. First of all, pre-test of the survey was conducted on 50 respondents, then the same form was administered to all the participants for collecting the data because there was no need for any correction or simplification which is needed for the improvement of data quality. During data collection process, 400 survey forms were distributed and face-to-face interview method was preferred for collecting data from the related working group. 4 survey forms were excluded from analysis due to mistakes and deficiencies and finally a total of 396 survey forms were subjected to the analysis. It is seen that $93.6 \%$ of respondents in the study were between the ages of 18 and 23 and the percentage of female students $(57.6 \%)$ was higher than male students $(42.4 \%)$. Considering the fact that respondents were undergraduate students, it was established that $41.4 \%$ of the sample of the study had 500 TL or below monthly, and it was between $501 \mathrm{TL}$ and $1000 \mathrm{TL}$ for $41.2 \%$ of the respondents. In terms of the education period at the university, it was almost normally distributed among respondents which means that respondents from each year of university education were reached in similar number. Top six counterfeit products that working group of study buy are clothes $(71.5 \%)$, perfume $(55.6 \%)$, bag or wallet $(41.7 \%)$, shoe $(40.9 \%)$, watch $(29.3 \%)$ and sunglasses $(29 \%)$, respectively.

Kurtosis and Skewness values were checked in order to reveal normality distribution of variables of the study and to show distribution structure (Gurbuz \& Sahin, 2016, p. 216). It was observed that data set regarding scales of perceived value, materialism and purchase intention of counterfeits of luxury products that were tested in the study had skewness value between $-1,140$ and 1,448, and the kurtosis value was between -1,094 and 1,382.

It can be stated that data supports the normal distribution since values of the research model are between -2 and +2 (Shao, 2002 cited in Basgoze \& Ozer, 2012, p. 64) and data show the characteristics of normal distribution. 


\subsection{Designing Survey Form and Scales of the Study}

In first part of the survey which consisted of three parts, respondents were asked whether they used any counterfeit products before and the survey was automatically finalized for those who had never used counterfeit products. The second part included items regarding the preferences of counterfeit products and socio-demographic features. Items of the scales which measure the variables of the study; namely, perceived value of counterfeit products, materialism and purchase intentions of counterfeits of luxury products, whose reliability and validity were tested were presented in the final part of the survey.

All of the scales used in the study were already utilized in other studies and their reliability and validity were tested, and the scales were adapted to the study after a thorough analysis of the related literature. Validity of the adapted scales was tested through translation-back translation procedure, expert panel and pilot study and items were presented to the respondents in a five point Likert scale fashion [(1) Strongly disagree... (5) Strongly agree)].

Further information regarding the scales were put forward below:

Perceived Value Scale: This scale was developed by Sweeney \& Soutar (2001) to measure consumers' perceived value of products. The scale is composed of four sub-dimensions aiming at measuring the benefits resulting from consumers' perceived quality/performance of products, positive feelings/emotions, decrease in cost, and enhancement of social sense of self. The scale has a total of 19 items including 6 quality related items, 5 emotion related items, 4 price related items and 4 sense of self related items. The adaptation of scale to counterfeit products and its Turkish version were performed by competent researchers in the field, and the scale was first administered to pilot group and to real sample group.

In order to test the structural validity of the scale, Exploratory Factor Analysis (EFA) was carried out by using Principal Component Analysis and Varimax Rotation Method. It was established that 19-item perceived value scale is composed of four factors and data complied with the four-factor structure of the scale. As a result of the analysis, it was found that factors explained $67.760 \%$ of variance and factor loadings of items were between 0.58 and 0.92. Bartlett's Test of Sphericity was significant $\left[\mathrm{x}^{2}(171)=3699.681, \mathrm{p}<0.01\right]$ and points to the fact that correlation relationships between items was appropriate for factor analysis, furthermore, Kaiser-Meyer-Olkin (KMO) value (0.874) where the lowest threshold is accepted to be 0.50 shows that the sample size was adequate for factor analysis (Gurbuz \& Sahin, 2016, p. 322). While Cronbach's Alpha Coefficient $(\alpha)$ which is calculated for determining internal consistency reliability of scale consisting of four dimensions and 19 items was overall 0.865 , in terms of each sub-dimension $\alpha$ coefficient was calculated as 0.880 for functional value (performance/quality), 0.871 for emotional value, 0.750 for functional value (price/value for money) and 0.916 for social value.

Materialism Scale: This scale was developed by Richins \& Dawson (1992) in order to measure the meaning and importance that consumers attach to tangible assets. The scale is composed of 18 items and three sub-dimensions which are regarding tangible assets as indicator of success (6 items), positioning acquisition of tangible assets at the centre of people's lives ( 7 items) and seeing tangible assets as necessity for satisfaction and happiness in life (5 items).

Within the scope of the study, adaptation of the scale and its Turkish version were performed by competent researchers in the field, and the scale was first administered to pilot group and to real sample group.

In order to test the structural validity of the scale, EFA was carried out by using Principal Component Analysis and Varimax Rotation Method. As a result of EFA, it was established that KMO sample adequacy value was 0.930 and the sample size was adequate for factor analysis. Bartlett's Test of Sphericity was significant $\left[\mathrm{x}^{2}\right.$ $(153)=4655.581, \mathrm{p}<0.01]$ and points to the fact that correlation relationships between items was appropriate for factor analysis. It was revealed that 18 -item scale was composed of three factors and complied with original structure, factors explained $67.576 \%$ of variance and factor loadings of items were between 0.56 and 0.87 . As a result of reliability analysis, overall Cronbach's Alpha Coefficient $(\alpha)$ of the scale consisting of three dimensions and 18 items was 0.939 ; with regards to each sub-dimension $\alpha$ coefficient was calculated as 0.894 for defining success, 0.892 for acquisition centrality and 0.891 for pursuit of happiness.

Behavioural Intentions Scale: The scale which was developed by Cronin et al. (2000) to measure the actions of consumers after purchasing counterfeit products was used in the study. The adaptation of the scale which is composed of 3 items and single dimension and its Turkish version were performed by competent researchers in the field, and the scale was first administered to pilot group and to real sample group.

It was found out that data complied with the single factor structure of the scale regarding the purchase intention 
of counterfeits of luxury brands, it explained $83.200 \%$ of variance and factor loadings of items were between 0.90 and 0.93 . It was revealed that KMO result was 0.744 , Bartlett's Test of Sphericity was significant $\left[\mathrm{x}^{2}(3)=\right.$ $730.795, \mathrm{p}<0.01]$ and Cronbach's Alpha Coefficient $(\alpha)$ of the scale was 0.899 .

\section{Findings}

Data collected in the study were analysed in SPSS program and mean, standard deviation and correlation coefficient values data collected from respondents regarding consumers' perceived value of counterfeit products, their materialistic tendencies and their purchase intentions of counterfeits of luxury brands were obtained. Results of these values are shown in Table 1.

Table 1. Mean, standard deviation and correlation coefficient values of variables $(\mathrm{N}=396)$

\begin{tabular}{llllll}
\hline Variables & Mean & SD & $\mathbf{1}$ & $\mathbf{2}$ & $\mathbf{3}$ \\
\hline 1. Perceived Value of Counterfeit Products (PVoCP) & 2.690 & 0.553 & $(0.865)$ & & \\
2. Materialism (M) & 2.333 & 0.831 & $0.098^{*}$ & $(0.939)$ & \\
3. Purchase Intention of Counterfeits of Luxury Brands (PIoCoLB) & 2.800 & 1.076 & $0.645^{* *}$ & -0.073 & $(0.899)$ \\
\hline
\end{tabular}

Note. ${ }^{*} \mathrm{p}<0.05,{ }^{* * \mathrm{p}}<0.01$.

As can be seen in the Table 1, both positive and negative weak and medium level correlations were observed in terms of correlations between variables of the study.

Hierarchical Regression Analysis was performed to test whether there is moderating of $\mathrm{M}$ in the effect of PVoCP on PIoCoLB. Within the scope of analysis, values of variance inflation factor (VIF) and tolerance were considered to determine whether there is multicollinearity between independent variables of the regression model. It is seen that VIF values of independent variables of the regression model were lower than 10 and their tolerance values were higher than 0.2 (Gurbuz \& Sahin, 2016, p. 273). In this regard, it can be stated that there is not any multicollinearity problem in the regression model.

In order to test the hypotheses of the study, first of all Simple Regression Analysis was performed and the effect of PVoCP on PIoCoLB was analysed with the created regression model as shown in Table 2 (H1). Based on the result of Simple Regression Analysis, it was observed that the relationship between PVoCP and PIoCoLB was significantly positive $(\beta=0.645, \mathrm{p}<0.01)$ and PVoCP explained $41 \%$ of variance of PIoCoLB. According to these results, $\mathrm{H} 1$ of the study was accepted. Based on these results, it can be concluded that perceived value of counterfeit products positively affect consumers' purchase intentions of counterfeits of luxury brands.

Table 2. Results of simple regression analysis of the investigation of the effect of perceived value of counterfeit products on purchase intention of counterfeits of luxury brands $(\mathrm{N}=396)$

\begin{tabular}{cllllll}
\hline Hypothesis & Variables & $\boldsymbol{\beta}$ & t & p & Tolerance & VIF \\
\hline $\mathrm{H} 1$ & $\mathrm{PVoCP} \rightarrow$ PIoCoLB & 0.645 & 16.735 & 0.000 & 1.000 & 1.000 \\
\hline$R^{2}=0.415$, Adjusted $R^{2}=0.414, F=280.065, p<0.01$ & & & & \\
Dependent Variable: Purchase Intention of Counterfeits of Luxury Brands & (PIoCoLB) \\
\hline
\end{tabular}

In Hierarchical Regression Analysis which was performed to test moderating effect, perceived value of counterfeit products (PVoCP) was added to the model as independent variable, purchase intention of counterfeits of luxury brands (PIoCoLB) as dependent variable and materialism (M) as moderator (Table 3).

As it is known, moderator is a qualitative or quantitative variable which affects the direction and strength of the relation between independent variable and dependent variable (Baron \& Kenny, 1986, p. 1174). According to this, in order for materialism to be a moderator, its interaction with independent variable (perceived value of counterfeit products) has to have a statistically positive effect on dependent variable (purchase intention of counterfeits of luxury brands). With this regards, in line with Gurbuz \& Sahin's (2016) suggestions, independent variable and moderator of the study were standardized ( $\mathrm{z}$ scores) and then interaction term was formed by multiplying standardized independent variable and moderator. After that, in the first step of Hierarchical Regression Analysis, standardized PVoCP and $\mathrm{M}$ variables were included into the analysis, in the second step interaction term ( $\mathrm{PVoCP} \times \mathrm{M})$ which is the result of multiplying perceived value of counterfeit products ( $\mathrm{PVoCP})$ and materialism $(\mathrm{M})$ was included. It is stated that instead of standardized beta coefficient $(\beta)$ unstandardized beta coefficient (B) should be reported while interpreting analysis regarding moderator (Aiken \& West, 1991 
cited in Gurbuz \& Bekmezci, 2012, p. 202).

Table 3. Results of hierarchical regression analysis of materialism's moderating role $(\mathrm{N}=396)$

\begin{tabular}{lllll}
\hline Variables & Model 1 & & Model 2 & \\
& $\mathrm{B}$ & $\mathrm{SE}$ & $\mathrm{B}$ & $\mathrm{SE}$ \\
\hline $\mathrm{PVoCP}$ & $0.708^{* *}$ & 0.041 & $0.710^{* *}$ & 0.041 \\
$\mathrm{M}$ & $-0.148^{* *}$ & 0.041 & $-0.152^{* *}$ & 0.041 \\
PVoCP x M & & & 0.036 & 0.041 \\
$\mathrm{R}$ & 0.659 & & 0.660 & \\
$\mathrm{R}^{2}$ & 0.434 & & 0.435 & \\
Adjusted R & 0.431 & & 0.431 & \\
$\Delta \mathrm{R}^{2}$ & 0.434 & & 0.001 & \\
\hline
\end{tabular}

Note. Dependent Variable: Purchase Intention of Counterfeits of Luxury Brands (PIoCoLB). ${ }^{* *} \mathrm{p}<0.01$.

In the first model, the results of Hierarchical Regression Analysis regarding moderating role of materialism show that variables of perceived value of counterfeit products $(\mathrm{PVoCP})$ and materialism $(\mathrm{M})$ significantly contribute to the regression model $[\mathrm{F}(2,393)=150.769, \mathrm{p}<0.01]$. Adjusted $\mathrm{R}^{2}$ value is 0.431 . This result shows that $43 \%$ of variance in consumers' purchase intentions of counterfeits of luxury brands (PIoCoLB) is explained by perceived value of counterfeit products $(\mathrm{PVoCP})$ and materialism $(\mathrm{M})$. It is seen that while there was a positive relationship between perceived value of counterfeit products and purchase intention of counterfeits of luxury brands, there was a negative relationship between materialism and purchase intention of counterfeits of luxury brands. Based on these results, it is concluded that consumers perceive a value of a brand even if it is a luxury brand, and as the perceived value increases, purchase intention of counterfeits of luxury brands increases, as well. However, as consumers' materialistic tendencies increase, their purchase intentions of counterfeit products decrease. Therefore, it can be concluded that materialistic tendencies of the consumers in the sample group prevent them from purchasing counterfeit products. In the second model, when perceived value of counterfeit products $(\mathrm{PVoCP})(\mathrm{B}=0.710, \mathrm{p}<0.01)$ and materialism $(\mathrm{M})(\mathrm{B}=-0.152, \mathrm{p}<0.01)$ interacted, any significant effect was not observed on purchase intention of counterfeits of luxury brands (PIoCoLB) $(B=0.036, p>0.05)[F(3,392)=$ 100.707, $\mathrm{p}<0.01]$. According to this finding, $\mathrm{H} 2$ is not supported. In other words, it was concluded that the relationship between PVoCP and PIoCoLB was not shaped by consumers' materialistic tendencies therefore materialism did not have any moderating role.

\section{Conclusion, Limitations \& Managerial Implications}

The research examines the relationship among perceived value of counterfeit products and purchase intention of the counterfeits of luxury brands and the moderating role of the materialism in this relationship. Also the model that is based on the conceptual framework is empirically tested. The results suggest that there is a statistical and considerable effect of the perceived value of counterfeit products and materialism on the purchase intention of the counterfeits of luxury brands. (While the perceived value has a positive effect, the materialism effect is negative.) However, there is no interaction effect of the perceived value of counterfeit products and materialism on purchase intention of the counterfeits of luxury brands.

According to these results, young consumers want to use luxury brands although they are counterfeits because of the perceived value of counterfeit products. These kinds of consumers are aware of the benefits (as social, functional and emotional benefits) of owning a handbag or watch of a counterfeit luxury brand.

On the other hand, our findings indicate that materialism significantly explains the purchase intention of counterfeits of luxury brands because of its effect. However, the direction of this effect is negative, this means that young consumers who are defined as materialist, would like to buy the original of the luxury brand instead of the counterfeit one. This result is in contradiction with some of the previous research (Albers-Miller, 1999; You \& Lee, 2009) because they get prestige without paying too much (Bloch et al., 1993; Tom et al., 1998; Ang et al., 2001). The reason behind that could be some quality differences between the original and counterfeit products although their physical appearance is identical to each other. Moreover the unconformity that the counterfeit users know the truth that the product they own is not the original one in reality.

Moreover, we can conclude that the situation is not related with financial issues. In this regard materialist consumers would force themselves and try to buy the original luxury brand instead of the counterfeit one.

Our study has a contribution to the literature to test the moderating role of materialism in the relationship between perceived value of counterfeit products and purchase intention of the counterfeits of luxury brands. 
Further research should focus on the limitations of this study. As there are more factors that affect the purchase intentions of consumers for counterfeit products. In addition, the research sample is from a reputable government University of Ankara. This could be a comparison between colleges and universities or maybe high schools can be added. Moreover cultural factors are always considered, here Turkish customers' behaviours are tested however this result could be different when it is measured in a European country or in a Far Eastern country.

According to the results of the study, the managerial implications should be towards the demand side of counterfeit products market. Unless the ethical point of view of consuming counterfeit product is mentioned and counterfeiting is positioned as a crime, the demand to counterfeit products will not decrease. The day that the customers feel the guilt of their behaviour will be the beginning of the end of the consumption of counterfeit products.

Governments including Turkey as well are hardly fighting to stop this illegal trend. They put legislations and regulations punishing the counterfeit producers even the related stuff like logistics, warehouses etc. However, the main issue is to reach the customers' minds. Therefore, the companies that own the original brand should take a crucial role in this matter. They can revise their marketing strategies and be more informative and leading. TV ads and social media could be used to reach the consumers directly. Also highlighting on the packages of the products (Chaudhry \& Stumpf, 2011) or visual materials within the packages (cards, stickers etc.) could be used to convince the customers not to consume counterfeits.

Brand extension strategies could be used to reduce this illicit trade. Target markets could capture the customers who tend to buy counterfeit products. Marketing managers could add new segments and provide new products that have the original brand etiquette however with low price for this kind of customers. This new segment goods can catch these customers who desire to own the original brand goods but who cannot afford to buy.

\section{References}

Aaker, D. A., \& Equity, M. B. (1991). Capitalizing on the value of a brand name. New York.

Albers-Miller, N. D. (1999). Consumer misbehavior: Why people buy illicit goods. Journal of Consumer Marketing, 16(3), 273-287. http://dx.doi.org/10.1108/07363769910271504

Ang, S. H., Cheng, P. S., Lim, E. A. C., \& Tambyah, S. K. (2001). Spot the difference: Consumer responses towards counterfeits. Journal of Consumer Marketing, 18(3), 219-235.

Baron, R. M., \& Kenny, D. A. (1986). The moderator-mediator variable distinction in social psychological research: Conceptual, strategic and statistical considerations. Journal of Personality and Social Psychology, 51(6), 1173-1182. http://dx.doi.org/10.1037/0022-3514.51.6.1173

Basgoze, P., \& Ozer, L. (2012). Gender effect on brand credibility and purchase relation: Does BC vary among different brands. International Journal of Arts and Commerce, 1(5), 58-69.

Belk, R. W. (1982). Acquiring, possessing, and collecting: Fundamental processes in consumer behavior. Marketing Theory: Philosophy of Science Perspectives, 185-190.

Belk, R. W. (1983). Worldly possessions: Issues and criticisms. Advances in Consumer Research, 10, 514-519.

Belk, R. W. (1984). Three scales to measure constructs related to materialism: Reliability, validity, and relationships to measures of happiness. Advances in Consumer Research, 11(1), 291-297.

Belk, R. W. (1985). Materialism: Trait aspects of living in the material world. Journal of Consumer Research, 12(3), 265-280. http://dx.doi.org/10.1086/208515

Bloch, P. H., Bush, R. F., \& Campbell, L. (1993). Consumer "accomplices" in product counterfeiting: A demand side investigation. Journal of Consumer Marketing, 10(4), 27-36. http://dx.doi.org/10.1108/07363769310047374

Chaudhry, P. E., \& Stumpf, S. A. (2011). Consumer complicity with counterfeit products. Journal of Consumer Marketing, 28(2), 139-151. http://dx.doi.org/10.1108/07363761111115980

Chuchinprakarn, S. (2003). Consumption of counterfeit goods in Thailand: Who are the patrons? European Advances in Consumer Research, 6, 48-53.

Cordell, V. V., Wongtada, N., \& Kieschnick, R. L. (1996). Counterfeit purchase intentions: Role of lawfulness attitudes and product traits as determinants. Journal of Business Research, 35(1), 41-53. http://dx.doi.org/10.1016/0148-2963(95)00009-7

Cronin, J. J., Brady, M. K., \& Hult, G. T. M. (2000). Assessing the effects of quality, value, and customer 
satisfaction on consumer behavioral intentions in service environments. Journal of Retailing, 76(2), 193-218. http://dx.doi.org/10.1016/S0022-4359(00)00028-2

Csikszentmihalyi, M., \& Rochberg-Halton, E. (1981). The meaning of things: Domestic symbols and the self. Cambridge: Cambridge University Press. http://dx.doi.org/10.1017/CBO9781139167611

Dodds, W. B., \& Monroe, K. B. (1985). The effect of brand and price information on subjective product evaluations. Advances in Consumer Research, 12(1), 85-90.

Dodds, W. B., Monroe, K. B., \& Grewal, D. (1991). Effects of price, brand, and store information on buyers' product evaluations. Journal of Marketing Research, 28(3), 307-319. http://dx.doi.org/10.2307/3172866

Dodge, H. R., Edwards, E. A., \& Fullerton, S. (1996). Consumer transgressions in the marketplace: Consumers' $\begin{array}{lllll}\text { perspectives. } & \text { Psychology } & \text { Marketing, } & \text { 13(8), } & \text { 821-35. }\end{array}$ http://dx.doi.org/10.1002/(SICI)1520-6793(199612)13:8\%3C821::AID-MAR7\%3E3.0.CO;2-H

Eisend, M., \& Schuchert-Guler, P. (2006). Explaining counterfeit purchases: A review and preview. Academy of Marketing Science Review, 12, 1-22.

Engizek, N., \& Sekerkaya, A. (2015a). Investigating the differences of consumers based on their high and low purchase intention of counterfeit luxury products. Journal of Marmara University Institute of Social Sciences, 11(43), 145-184.

Engizek, N., \& Sekerkaya, A. (2015b). Is the price only motivation source to purchase counterfeit luxury products? Journal of Academic Research in Economics, 7(1).

Fernandes, C. (2013). Analysis of counterfeit fashion purchase behaviour in UAE. Journal of Fashion Marketing and Management: An International Journal, 17(1), 85-97. http://dx.doi.org/10.1108/13612021311305155

Fitzmaurice, J., \& Comegys, C. (2006). Materialism and social consumption. Journal of Marketing Theory and Practice, 14(4), 287-299.

Furnham, A., \& Valgeirsson, H. (2007). The effect of life values and materialism on buying counterfeit products. The Journal of Socio-Economics, 36(5), 677-685. http://dx.doi.org/10.1016/j.socec.2007.01.004

Gentry, J. W., Putrevu, S., \& Shultz, C. J. (2006). The effects of counterfeiting on consumer search. Journal of Consumer Behaviour, 5(3), 245-256. http://dx.doi.org/10.1002/cb.176

Gentry, J. W., Putrevu, S., Shultz II, C., \& Commuri, S. (2001). How now Ralph Lauren? The separation of brand and product in a counterfeit culture. NA-Advances in Consumer Research, 28, 258-265.

Grewal, D., Monroe, K. B., \& Krishnan, R. (1998). The effects of price-comparison advertising on buyers' perceptions of acquisition value, transaction value, and behavioral intentions. Journal of Marketing, 62(2), 46-59. http://dx.doi.org/10.2307/1252160

Grossman, G. M., \& Shapiro, C. (1988). Foreign counterfeiting of status goods. The Quarterly Journal of Economics, 103(1), 79-100. http://dx.doi.org/10.2307/1882643

Gurbuz, S., \& Bekmezci, M. (2012). The mediating and moderating role of affective commitment in the effect of human resource management practices on turnover intention of knowledge workers. Istanbul University Journal of the School of Business Administration, 41(2), 189-213.

Gurbuz, S., \& Sahin, F. (2016). Research methods in social sciences: Philosophy-method-analysis (3rd ed.). Ankara: Seckin Publication.

Hennigs, N., Wiedmann, K. P., Klarmann, C., Behrens, S., Jung, J., \& Hwang, C. S. (2015). When the original is beyond reach: Consumer perception and demand for counterfeit luxury goods in Germany and South Korea. Luxury Research Journal, 1(1), 58-75. http://dx.doi.org/10.1504/LRJ.2015.069803

Hieke, S. (2010). Effects of counterfeits on the image of luxury brands: An empirical study from the customer perspective. Journal of Brand Management, 18(2), 159-173. http://dx.doi.org/10.1057/bm.2010.28

http://www.resmigazete.gov.tr/eskiler/2017/01/20170110-9.htm

Kotler, P. H. (1991). Marketing management: Analysis, planning, and control (8th ed.). Englewood Cliffs, NJ: Prentice-Hall, Inc.

Kurtulus, K. (2010). Research methods. Istanbul: Turkmen Publication.

Lu, L. C., \& Lu, C. J. (2010). Moral philosophy, materialism, and consumer ethics: An exploratory study in Indonesia. Journal of Business Ethics, 94(2), 193-210. http://dx.doi.org/10.1007/s10551-009-0256-0 
Monroe, K. B., \& Krishnan, R. (1985). The effect of price on subjective product evaluations. Perceived Quality, 1, 209-232.

Netemeyer, R. G., Burton, S., \& Lichtenstein, D. R. (1995). Trait aspects of vanity: Measurement and relevance to consumer behavior. Journal of Consumer Research, 21(4), 612-626. http://dx.doi.org/10.1086/209422

Netemeyer, R. G., Krishnan, B., Pullig, C., Wang, G., Yagci, M., Dwane, D., Ricks, J., \& Wirth, F. (2004). Developing and validating measures of facets of customer-based brand equity. Journal of Business Research, 57(2), 209-224. http://dx.doi.org/10.1016/S0148-2963(01)00303-4

Nia, A., \& Zaichkowsky, J. L. (2000). Do counterfeits devalue the ownership of luxury brands? Journal of Product \& Brand Management, 9(7), 485-497. http://dx.doi.org/10.1108/10610420010351402

OECD/EUIPO. (2016). Trade in Counterfeit and Pirated Goods: Mapping the Economic Impact. OECD Publishing, Paris.

Penz, E., \& Stottinger, B. (2005). Forget the Areal@ Thingbtake the copy! An explanatory model for the volitional purchase of counterfeit products. Advances in Consumer Research, 32, 568-575.

Penz, E., \& Stottinger, B. (2008). Original brands and counterfeit brands-do they have anything in common? Journal of Consumer Behaviour, 7(2), 146-163.

Rao, A. R., \& Monroe, K. B. (1989). The effect of price, brand name, and store name on buyers' perceptions of product quality: An integrative review. Journal of Marketing Research, 351-357. http://dx.doi.org/10.2307/3172907

Richins, M. L. (1994). Valuing things: The public and private meanings of possessions. Journal of Consumer Research, 21(3), 504-521. http://dx.doi.org/10.1086/209414

Richins, M. L., \& Dawson, S. (1992). A consumer values orientation for materialism and its measurement: Scale development and validation. Journal of Consumer Research, 19(3), 303-316. http://dx.doi.org/10.1086/209304

Sheth, J. N., Newman, B. I., \& Gross, B. L. (1991). Why we buy what we buy: A theory of consumption values. Journal of Business Research, 22(2), 159-170. http://dx.doi.org/10.1016/0148-2963(91)90050-8

Sun, G., D'Alessandro, S., \& Johnson, L. (2014). Traditional culture, political ideologies, materialism and luxury consumption in China. International Journal of Consumer Studies, 38(6), 578-585. http://dx.doi.org/10.1111/ijcs.12117

Swami, V., Chamorro-Premuzic, T., \& Furnham, A. (2009). Faking it: Personality and individual difference predictors of willingness to buy counterfeit goods. The Journal of Socio-Economics, 38(5), 820-825. http://dx.doi.org/10.1016/j.socec.2009.03.014

Sweeney, J. C., \& Soutar, G. N. (2001). Consumer perceived value: The development of a multiple item scale. Journal of Retailing, 77(2), 203-220. http://dx.doi.org/10.1016/S0022-4359(01)00041-0

Tom, G., Garibaldi, B., Zeng, Y., \& Pilcher, J. (1998). Consumer demand for counterfeit goods. Psychology \& Marketing, $15(5)$ 405-421. http://dx.doi.org/10.1002/(SICI)1520-6793(199808)15:5\%3C405::AID-MAR1\%3E3.0.CO;2-B

Vigneron, F., \& Johnson, L. W. (1999). A review and a conceptual framework of prestige-seeking consumer behavior. Academy of Marketing Science Review, 1, 1-15.

Walker, N. (1977). Behaviour and misbehaviour: Explanations and non-explanations. Oxford: Blackwell.

Wan, W. W., Luk, C. L., Yau, O. H., Alan, C. B., Sin, L. Y., Kwong, K. K., \& Chow, R. P. (2009). Do traditional Chinese cultural values nourish a market for pirated CDs? Journal of Business Ethics, 88(1), 185-196. http://dx.doi.org/10.1007/s10551-008-9821-1

Wee, C. H., Ta, S. J., \& Cheok, K. H. (1995). Non-price determinants of intention to purchase counterfeit goods: An exploratory study. International Marketing Review, 12(6), 19-46. http://dx.doi.org/10.1108/02651339510102949

Wiedmann, K. P., Hennigs, N., \& Siebels, A. (2007). Measuring consumers' luxury value perception: A cross-cultural framework. Academy of Marketing Science Review, 7(7), 333-361.

Wilke, R., \& Zaichkowsky, J. L. (1999). Brand imitation and its effects on innovation, competition, and brand equity. Business Horizons, 42(6), 9-18. http://dx.doi.org/10.1016/S0007-6813(99)80033-0 
Yoo, B., \& Lee, S. H. (2009). Buy genuine luxury fashion products or counterfeits? Advances in Consumer Research, 36, 280-286.

Zeithaml, V. A. (1988). Consumer perceptions of price, quality, and value: A means-end model and synthesis of evidence. Journal of Marketing, 52, 2-22. http://dx.doi.org/10.2307/1251446

\section{Appendix A}

\section{Scales (Perceived Value-Materialism-Purchase Intention)}

\begin{tabular}{|c|c|}
\hline Variable & Items \\
\hline \multicolumn{2}{|c|}{ PERCEIVED VALUE (Source: Sweeney and Soutar, 2001) } \\
\hline \multirow{6}{*}{$\begin{array}{l}\text { Functional Value } \\
\text { (Performance/Quality) (FV1) }\end{array}$} & Counterfeit products have consistent quality. \\
\hline & Counterfeit products are well made. \\
\hline & Counterfeit products have acceptable standard of quality. \\
\hline & Counterfeit products have poor workmanship.* \\
\hline & Counterfeit products would not last a long time.* \\
\hline & Counterfeit products would perform consistently. \\
\hline \multirow[t]{5}{*}{ Emotional Value (EV) } & Counterfeit products are ones that I would enjoy. \\
\hline & Counterfeit products would make me want to use them. \\
\hline & Counterfeit products are ones that I would feel relaxed about using. \\
\hline & Counterfeit products would make me feel good. \\
\hline & Counterfeit products would give me pleasure. \\
\hline \multirow{4}{*}{$\begin{array}{l}\text { Functional Value (Price/Value for } \\
\text { Money) (FV2) }\end{array}$} & Counterfeit products are reasonably priced. \\
\hline & Counterfeit products offer value for money. \\
\hline & Counterfeit products are good products for the price. \\
\hline & Counterfeit products would be economical. \\
\hline \multirow[t]{4}{*}{ Social Value (SV) } & Counterfeit products would help me to feel acceptable. \\
\hline & Counterfeit products would improve the way I am perceived. \\
\hline & Counterfeit products would make a good impression on other people. \\
\hline & Counterfeit products would give their owner social approval. \\
\hline \multicolumn{2}{|c|}{ MATERIALISM (Source: Richins and Dawson, 1992) } \\
\hline \multirow[t]{6}{*}{ Defining Success (DS) } & I admire people who own expensive homes, cars and clothes. \\
\hline & $\begin{array}{l}\text { Some of the most important achievements in life include acquiring material } \\
\text { possessions. }\end{array}$ \\
\hline & $\begin{array}{l}\text { I don't place much emphasis on the amount of material objects people own as a } \\
\text { sign of success.* }\end{array}$ \\
\hline & The things I own say a lot about how well I'm doing in life. \\
\hline & I like to own things that impress people. \\
\hline & I don't pay much attention to the material objects other people own.* \\
\hline \multirow[t]{7}{*}{ Acquisition Centrality (AC) } & I usually buy only the things I need.* \\
\hline & I try to keep my life simple, as far as possessions are concerned.* \\
\hline & The things I own aren't all that important to me.* \\
\hline & I enjoy spending money on things that aren't practical. \\
\hline & Buying things gives me a lot of pleasure. \\
\hline & I like a lot of luxury in my life. \\
\hline & I put less emphasis on material things than most people I know.* \\
\hline \multirow[t]{5}{*}{ Pursuit of Happiness (PoH) } & I have all the things I really need to enjoy life.* \\
\hline & My life would be better if I owned certain things I don't have. \\
\hline & I wouldn't be any happier if I owned nicer things.* \\
\hline & I would be happier if I could afford to buy more things. \\
\hline & It sometimes bothers me quite a bit that I can't afford to buy all the things I'd like. \\
\hline \multicolumn{2}{|c|}{ PURCHASE INTENTION of COUNTERFEITS of LUXURY BRANDS (PIoCoLB) (Source: Cronin et al., 2000) } \\
\hline & The probability that I will use counterfeit products is high. \\
\hline & The likelihood that I would recommend counterfeit products to a friend is high. \\
\hline & $\begin{array}{l}\text { If I had to do it over again, I would make the same choice of buying counterfeit } \\
\text { products. }\end{array}$ \\
\hline
\end{tabular}

Note. *Denotes items that are reverse scored. 


\section{Copyrights}

Copyright for this article is retained by the author(s), with first publication rights granted to the journal.

This is an open-access article distributed under the terms and conditions of the Creative Commons Attribution license (http://creativecommons.org/licenses/by/4.0/). 